\title{
Cross-Cultural Correlates of the Ownership of Private Property
}

\author{
FLoyd Webster Rudmin
}

Faculty of Law and School of Business, Queen's University

\begin{abstract}
Simmons' (1937) data base of 109 variables measured on 71 societies was reanalyzed. Reliability comparisons were made with Murdock's (1967) Ethnographic Atlas. Eliminated were 3 of Simmons' cultures because of duplicated sampling within culture clusters, 12 variables because of missing data, 7 variables because of invariance, and 1 variable for doubtful reliability. A conservative analysis $(p<$ .0001 ) showed private property in land and chattel to correlate with 21 variables falling into 3 clusters, interpretively labelled (1) the social ecology of agriculture, (2) social and matcrial stratification, and (3) social security. Subject to the limitations of archived data and to the indeterminancy of correlational analysis, these findings support arguments that private property arose in agricultural society, but not theories that property is a patriarchal, antifemale institution. Speculations based on psychological literature suggest that private property empowers the defense of the self. (0) 1992 Academic Press, Inc.
\end{abstract}

For more than two millennia, the social institution of private property has been a central topic and a motivating issue for cross-cultural research (Rudmin, 1988a, 1988b). Ethnographic evidence was commonly cited by the classical political economic and social theorists of earlier centuries (e.g., Locke, 1690/1952; Rousseau, 1754/1964; Engels, 1884/1902; Spencer 1879/1893; Veblen, $1898 ; 1899 / 1912$ ). It is still cited in current versions of those debates (e.g., Averkieva, 1961; Coontz and Henderson, 1986; Posner, 1980). Despite the apparent importance and appeal of crosscultural studies of property and ownership, the social science literature on these topics has been scattered and isolated (see Rudmin, Belk and Furby's 1987 bibliography of 1580 social science citations.) Furthermore, there has been a noticeable lack of quantitative cross-cultural research on property. In 1949, Murdock lamented that "a really adequate study of

The late Raoul Naroll first encouraged me in this work and suggested that I examine Simmons' data base. During the preparation of this paper, funding was provided by the Social Sciences and Humanities Research Council of Canada and by Queen's University. Send requests for reprints to Floyd W. Rudmin, Faculty of Law, Queen's University, Kingston, Ontario, Canada K7L 3N6. BITNET: RUDMINF@QUCDN. 
property rights and inheritance in cross-cultural perspective still remains to be made" (p. 39). In 1980, Levinson and Malone lamented, "It is surprising to find that some thirty years later, the situation has hardly changed" (p. 135). And now another decade later, there are still no adequate studies of the cultural correlates of private ownership.

In the late 19th and early 20th centuries, concerted efforts were made to collate disparate ethnographic evidence for the purposes of supporting or refuting political economic and social theories. There were many unsystematic, often ideologically biased, nonquantitative, cross-cultural studies of property (e.g., Ensor, 1844; Fustel de Coulanges, 1885; 1891a, 1891b; Guyot, 1895; LaFargue, 1885; 1890; 1892; Laveleye, 1878; 1891; Letourneau, 1892; Lewinski, 1913; Petrucci, 1905; Westermarck, 1908a, 1908b). It was not until Hobhouse, Wheeler and Ginsberg's 1915 study The Material Culture and Social Institutions of the Simpler Peoples that a quantitative cross-cultural study of property was available. It incorporated hundreds of societies, from across the globe, and tried to identify patterns of relationships by means of statistical methods. However, as a pioneering work, it had many faults: (1) the sampling of cultures was neither random nor stratified and suffered from unbalanced representation of societies by culture groups and by geographic regions; (2) for neither the ethnographies nor the codings of ethnographies was reliability established; and (3) the only statistic was the proportion of societies of a cultural type that exhibited a characteristic variable.

The next cross-cultural, quantitative study of property was undertaken by Simmons in 1937. He examined 109 cultural traits, including several concerning property, for 71 societies "selected with due regard to climatic zones, geographical distribution, racial differences, and cultural areas" (Simmons, 1937, p. 495). His purpose was to confirm the theories of his mentors, Sumner and Keller (1927), who had relied upon the traditional selective and nonquantitative use of ethnographies. Although Simmons' (1937) stratified sampling was an improvement over that done by Hobhouse, Wheeler, and Ginsberg (1915), his work did have several faults: (1) as with the 1915 study, reliability was not established for the ethnographies or the codings of ethnographies; and (2) although Simmons' use of the phi coefficient was an improvement over the proportion statistic used in the 1915 study, Simmons had to collapse 4-point ordinal data to a binary nominal scale in order to make the calculations, thus losing much of the power of his codings. For his 1945 study The Role of the Aged in Primitive Society, Simmons coded another 112 traits for these 71 societies.

A critical look at subsequent uses of Simmons' 1937 data reveals further difficulties and dangers that need to be avoided. In 1962, Gouldner and Peterson reported using Simmons' data for a factor analytic study of technology and the moral order. Factor analysis requires (1) equal interval rather than ordinal measurements, (2) no missing data, (3) no invariance, 
and (4) fewer variables than cases. The first concern was simply ignored, and the other three were achieved by deleting 52 of the 109 variables and then fabricating median values for the remaining cases with missing data. Deletion criteria were (a) missing values on 20 or more of the 71 cases, or (b) an unspecified degree of invariance. From these machinations, one might well conclude that factor analysis is simply inappropriate for these data.

There also appears to be risk of a general carelessness when using archived data bases. For example, Gouldner and Peterson (1962, p. 17) admitted that one trait, "Trade," was "eliminated by mistake," but they failcd to cxplain why the variables "Debt-Relations," with 32 missing values, "Matrilineal Descent," with 25 missing values, and "Matrilineal Inheritance," with 28 missing values, were not deleted. Gouldner and Peterson's (1962) Appendix B shows these variables to have two, two, and three missing values respectively. Comparing missing value reports in that appendix versus those in Simmons' 1937 Table 2 or his 1945 Table 6 shows disagreement on all but a few variables. Usually Simmons reports more missing data, but sometimes, as with "Permanency of Residence," Gouldner and Peterson report more. No matter how these discrepancies are interpreted or resolved, they are not cause for confidence in the research or the ensuing discussions.

Finally, Gouldner and Peterson's (1962) results, in conjunction with those of subsequent studies by Bloombaum (1968) and by Heise, Lenski, and Wardwell (1976), well demonstrate the indeterminacy of multivariate analyses. Gouldner and Peterson identified 10 to 15 factors in their correlation matrix, but limited their discussion to four; "Lineality," "Sex Dominance," "Technology," and "Apollonianism." In none of these did the traits of private ownership have appreciable weight. Bloombaum (1968) subjected the same correlation matrix to multidimensional scaling and identified four clusters of traits. Private property in land and in objects appeared in the "Settledness" cluster and not in the "Nomadism," "Patricentricity," or "Matricentricity" clusters. Heise, Lenski, and Wardwell (1976) reinterpreted Bloombaum's four clusters as two dimensions, and then reanalyzed the same correlation matrix and concluded that two factors were best: "Evolution-Development" and "Lineality." Principal components factoring of data from Murdock's (1967) Ethnographic Atlas replicated these two factors. Private property in land and in objects had moderate positive weights in the first factor and weak or negative weights in the second. Maximum-likelihood factoring of Murdock's data produced 11 factors, with the property variables loading with "Complex, Sedentary Settlements," "Large, Dense Settlements," "Multilevel Political Hierarchy," "Elites or Social Classes," and "Craft Specialists." Given the indeterminacy of these multivariate analyses, Heise, Lenski, and Wardwell's (1976) search for replication was indeed appropriate. 
Clearly there has been a history of incautious readiness to exploit crosscultural data for theoretical debate and for speculation about property issues. Before further indulgence in that direction, it is imperative to establish a confident and replicated record of just what are the crosscultural correlates of private ownership. Before undertaking to test new hypotheses and to compile new data, it is necessary to first establish what are the existing observations based on the existing data bases. Archived data are fundamental to the comparative ethnographic enterprise, and the statistical technology is now available to resurrect and reanalyze the older data bases. The purpose of this study was to complete such a reanalysis of Simmons' (1937) data, with the objective of identifying cultural correlates of the practice of private ownership. This is the first in a series of such reexaminations. The methodology of conservatively analyzing older data bases will be emphasized, and speculative or theoretical discussion will be minimized.

\section{METHOD}

Comparison data for the examination of sampling and of reliability was sought in Murdock's (1967) Ethnographic Atlas. This source was preferred to his more recent Atlas of World Cultures (Murdock, 1981) because the former groups 862 societies into 412 "culture clusters" on criteria of cultural similarity, whereas the latter groups only 563 societies into only 150 "cultural provinces" on criteria of geographic sampling symmetry. As shown in Table 1, if Ethnographic Atlas (1967) codings were discrepant from codings in subsequent issues of Ethnography (1967, pp. 481-486; 1968, pp. 218-224) or in the Atlas of World Cultures (1981), the more recent codings were presumed to be more accurate. Murdock (1967) coded data for all but five of Simmons' 71 societies. However, for four of these five, Murdock published codings in Ethnography. Thus, only the Euahlayi, a southeastern Australian society (Parker, 1905), were without comparison data.

On seven occasions, Simmons and Murdock used different names for the same society: Bakongo/Kongo, Akamba/Kamba, Fan/Fang, Dahomi/Fon, Norse/Scandinavians, Arunta/Aranda, and Eskimo Point Barrow/Tareumiut. On 11 occasions, Simmons' tribe name corresponded to Murdock's culture cluster name. For four of these (Hottentots, Albanians, Banks Islanders, Araucanians), Murdock's cluster contained only one society, thus posing no difficulty for comparisons. However, for the other seven (Bushmen, Tuareg, Berbers, Mongols, Munda, Pomo, Arawak), arbitrary criteria were needed to select a comparison society from several alternatives. The criteria used here were (1) that the ethnography be as recent as possible but prior to Simmons' work in the 1930's and (2) that there be minimal missing data for Murdock's property inheritance variables in Columns 74 and 76. 
TABLE 1

Combined Simmons-Murdock Ethnographic Data Base

\begin{tabular}{|c|c|c|c|c|c|c|}
\hline \multicolumn{2}{|c|}{ Simmons' codings } & \multicolumn{5}{|c|}{ Murdock's Ethnographic Atlas codings } \\
\hline \multirow[b]{2}{*}{ Name } & \multirow{2}{*}{$\begin{array}{c}\text { Missing } \\
\text { data }\end{array}$} & \multicolumn{2}{|r|}{ Culture clusters } & \multicolumn{3}{|c|}{ Local ethnographies } \\
\hline & & Code & Name & Name & Code & Date \\
\hline \multicolumn{7}{|c|}{ African Societies } \\
\hline Bushmen & 24 & 002 & Bushmen & Naron & Аa 7 & 1910 \\
\hline Hottentots & 26 & 003 & Hottentot & Nama & Aa 3 & 1860 \\
\hline Kafirs (Xosa) & $25^{a}$ & 004 & Nguni & Xhosa & Ab 11 & 1850 \\
\hline Bakongo & 11 & 011 & Lower Congo & Kongo & Ac 14 & 1900 \\
\hline Akamba & $36^{a}$ & 026 & Kenya Highlands & Kamba & Ad34 & 1910 \\
\hline Fan & 40 & 035 & Fang-Dzem & Fang & Ae 3 & 1905 \\
\hline Dahomi & 47 & 044 & Ewe-Fon & Fon & Af 1 & 1890 \\
\hline Ashanti & 16 & 045 & Akan & Ashanti & Af 3 & 1895 \\
\hline Vai & $19^{a}$ & 048 & Mende-Temme & Vai & Af 58 & 1900 \\
\hline Mang-Betu & $37^{a}$ & 073 & Mangbetu & Mangbetu & $\mathrm{Ai} 11$ & 1900 \\
\hline Shilluk & 26 & 076 & Fung & Shilluk & $\mathrm{Ai} 6$ & 1910 \\
\hline Lango & $16^{a}$ & 080 & S. Nilotes & Lango & $\mathrm{Aj} 4$ & 1920 \\
\hline \multicolumn{7}{|c|}{ Circum-Mediterranean Societies } \\
\hline Tuareg & $62^{a}$ & 105 & Tuareg & Ahaggaren & Cc 9 & 1900 \\
\hline Rwala & 27 & 108 & Bedouin Arabs & Rwala & $\mathrm{Cj} 2$ & 1913 \\
\hline Berbers & 36 & 109 & Moroccan Berbers & Shluh & Cd 5 & 1920 \\
\hline Albanians & 40 & 115 & Albanians & Gheg & $\mathrm{Ce} 1$ & 1910 \\
\hline Norse & $29^{a}$ & 122 & Scandinavians & Icelanders & $\mathrm{Cg} 2$ & 1100 \\
\hline Lapps & 49 & 123 & Lapps & Lapps & $\mathrm{Cg} 4$ & 1950 \\
\hline Hebrews & $34^{a}$ & 137 & Jews & Hebrews & $\mathrm{Cj} 3$ & -621 \\
\hline \multicolumn{7}{|c|}{ East Eurasian Societies } \\
\hline Kazaks & 26 & 148 & Turkestan & Kazak & Eb 1 & 1885 \\
\hline Mongols & 35 & 149 & Mongols & Monguor & Eb 2 & 1909 \\
\hline Yakut & 25 & 153 & Yakut & Yakut & Ec 2 & 1890 \\
\hline Yukaghir & 29 & 154 & Yukaghir & Yukaghir & Ec 6 & 1900 \\
\hline Chukchee & 14 & 155 & Paleo-Siberians & Chukchee & Ec 3 & 1900 \\
\hline Ainu & 11 & 157 & Ainu & Ainu & Ec 7 & 1880 \\
\hline Munda & 36 & 176 & Munda & Hill Bhuiya & Eg 7 & 1930 \\
\hline Todas & 26 & 180 & Nilgiri Hills & Toda & $\mathrm{Eg} 4$ & 1900 \\
\hline Veddas & 23 & 183 & Vedda & Vedda & Eh 4 & 1900 \\
\hline Andamanese & 25 & 186 & Andaman Islands & Andamanese & Eh 1 & 1860 \\
\hline Chin & $38^{a}$ & 188 & Kuki-Chin & Chin & Ei 19 & 1940 \\
\hline Sema Nagas & 28 & 191 & Naga & Sema & Ei 16 & 1910 \\
\hline Palaung & 36 & 193 & Palaung-wa & Palaung & Ei 18 & 1920 \\
\hline Semang & 16 & 204 & Semang & Semang & $\mathrm{Ej} 3$ & 1920 \\
\hline \multicolumn{7}{|c|}{ Insular Pacific Societies } \\
\hline Bontoc Igorot & $19^{a}$ & 209 & Highland Luzon & Bontok Igorot & Ia & 1900 \\
\hline Iban & 10 & 212 & Borneo & Iban & Ib & 1950 \\
\hline Arunta & $55^{b}$ & 230 & Central Australia & Aranda & Id 1 & 1896 \\
\hline Dieri & 22 & 230 & Central Australia & Dieri & Id 4 & 1900 \\
\hline Euahlayi & 53 & - & - & - & - & 1905 \\
\hline Tasmanians & 45 & 232 & Tasmania & Tasmanians & Id 8 & 1830 \\
\hline
\end{tabular}


TABLE 1-Continued

\begin{tabular}{|c|c|c|c|c|c|c|}
\hline \multicolumn{2}{|c|}{ Simmons' codings } & \multicolumn{5}{|c|}{ Murdock's Ethnographic Atlas codings } \\
\hline \multirow[b]{2}{*}{ Name } & \multirow{2}{*}{$\begin{array}{c}\text { Missing } \\
\text { data }\end{array}$} & \multicolumn{2}{|r|}{ Culture clusters } & \multicolumn{3}{|c|}{ Local ethnographies } \\
\hline & & Code & Name & Name & Code & Date \\
\hline Kiwai & 9 & 235 & Gulf of Papua & Kiwai & Ie 13 & 1920 \\
\hline Mafulu & 21 & 240 & E. Papuans & Mafulu & Ie 25 & 1920 \\
\hline Trobriands & 23 & 256 & Massim & Trobrianders & $\operatorname{Ig} 2$ & 1914 \\
\hline Banks Ids. & 24 & 263 & Banks Islands & Mota & Ih 1 & 1890 \\
\hline Samoans & 16 & 274 & W. Polynesians & Samoans & Ii 1 & 1920 \\
\hline Maori & 23 & 275 & S. Polynesians & Maori & $\mathbf{I} \mathbf{j}$ & 1820 \\
\hline \multicolumn{7}{|c|}{ North American Societies } \\
\hline Eskimo Pt. B. & $51^{b}$ & 279 & Central \& E. Eskimo & Tareumiut & Na 2 & 1880 \\
\hline Eskimo Polar & 15 & 279 & Central \& E. Eskimo & Polar Eskimo & $\mathrm{Na} 14$ & 1880 \\
\hline Eskimo Lab. & $43^{b}$ & 279 & Central \& E. Eskimo & Lab. Eskimo & $\mathrm{Na} 23$ & 1890 \\
\hline Chippewa & 47 & 282 & Ojibwa & Chippewa & $\mathrm{Na} 36$ & 1917 \\
\hline Haida & 21 & 288 & Tlingit-Haida & Haida & $\mathrm{Nb} 1$ & 1875 \\
\hline Kwakiutl & 17 & 290 & Kwakiutl-Bellacoola & Kwakiutl & $\mathrm{Nb} 3$ & 1890 \\
\hline Pomo & 31 & 298 & Pomo-Yuki & E. Pomo & Nc 18 & 1850 \\
\hline Kutenai & 60 & 312 & Kutenai & Kutenai & Nd 7 & 1880 \\
\hline Crow & 58 & 315 & Upper Missouri & Crow & $\mathrm{Ne} 4$ & 1870 \\
\hline Omaha & 23 & 319 & Prajije Siouans & Omaha & Nf 3 & 1860 \\
\hline Menomini & 53 & 320 & Central Algonkians & Menomini & Nf 9 & 1870 \\
\hline Iroquois & 23 & 231 & Iroquois & Iroquois & $\mathrm{Ng} 10$ & 1750 \\
\hline Yuchi & 45 & 323 & Cherokee-Yuchi & Yuchi & $\mathrm{Ng} 11$ & 1750 \\
\hline Creek & 28 & 324 & Muskogee & Creek & $\mathrm{Ng} 3$ & 1800 \\
\hline Hopi & 43 & 330 & W. Pueblos & Hopi & Nh 18 & 1920 \\
\hline Navaho & 26 & 331 & Navaho & Navaho & $\mathrm{Nh} 3$ & 1940 \\
\hline Seri & 39 & 334 & Seri & Seri & $\mathrm{Ni} 4$ & 1900 \\
\hline Aztecs & 13 & 341 & Aztec & Aztec & $\mathrm{Nj} 2$ & 1520 \\
\hline \multicolumn{7}{|c|}{ South American Societies } \\
\hline Arawak & 40 & 362 & S. Venezuelan Arawak & Wapishana & Sc 5 & 1900 \\
\hline Witoto & 17 & 379 & Witoto & Witoto & Se 6 & 1910 \\
\hline Jivaro & 59 & 380 & Jivaro & Jivaro & Se 3 & 1930 \\
\hline Incas & 63 & 386 & Highland Peru & Inca & Sf 1 & 1530 \\
\hline Araucanians & 26 & 388 & Araucanians & Mapuche & Sg 2 & 1880 \\
\hline Yahgan & 43 & 390 & Yahgan & Yahgan & $\mathrm{Sg} 1$ & 1865 \\
\hline Abipones & 50 & 392 & Guaycuru & Abipon & Sh 3 & 1800 \\
\hline Lengua & 26 & 393 & Mascoi & Lengua & Sh 9 & 1890 \\
\hline
\end{tabular}

${ }^{a}$ Data corrected or completed from Ethnography (1962-1968) or 1981 Atlas.

${ }^{b}$ This society duplicates a sample from its culture cluster.

On two occasions, it was evident that Simmons had resampled the same culture cluster. In these instances, the societies with the least missing data were selected for inclusion in the study. By this criterion, as shown in Table 1, the Arunta, Point Barrow Eskimo, and Labrador Eskimo societies were eliminated from further consideration. 
On one occasion, societies from Simmons' sample violated the " 3 degree rule" (Murdock, 1967). This heuristic requires that sampled societies be separated by at least 3 degrees of longitude and 3 degrees of latitude (more at higher longitudes) if the effects of cultural borrowing are to be minimized. The societies in violation were the Creek $(34 \mathrm{~N}, 86 \mathrm{~W})$ and the Yuchi $(35 \mathrm{~N}, 86 \mathrm{~W})$. However, for several reasons, neither society was deleted for this violation. First, it is not clear that equal units of distance are equal barriers to cultural borrowing for all societies in all geographies. Second, the "3-degree rule" is redundant since Murdock's (1967) culture clusters already group societies that are similar due to prolonged contact. Finally, the validity and reliability of locating societies by points on the globe are doubtful. Comparison of Murdock's 1967 Ethnographic Atlas and his 1981 Atlas of World Cultures shows that, of the 58 of Simmons' societies with reported latitude and longitude, 20 required corrections, and 11 of these corrections were 2 degrees or more. For the Rwala and the Lengua, corrections in latitude were 9 degrees. With such a frequency and range of measurement error, decisions based on 3 degrees are unreasonable.

Case data were taken from Simmons' (1937) Table 2 and were quantified according to the description on page 497: $0=$ "o absence or nonappearance of the trait, when definitely indicated in the sources"; $1=$ "- incipient presence, slight elaboration, or cultural unimportance of the trait"; 2 = " = presence without dominance, moderate elaboration, or intermediate importance"; $3=$ " + dominance, marked elaboration, or strong social importance of the trait"; missing: "lack of information on the subject in the sources." In order to calculate nominal scale phi coefficients, Simmons had collapsed his 4-point ordinal scale to a 2-point nominal scale, with "o" and "-" collapsing to "o" and with "+" and " =" collapsing to " $+"$. In the present analysis, the full ordinal range of Simmons' case codings was maintained and exploited in the analysis.

Simmons' 109 variables appear in Table 2, along with score frequencies for the 68 societies examined. As shown in Table 2, 12 variables had missing data on 40 or more of the societies. Another seven variables had very skewed distributions and low variance. Because both of these conditions impair the calculation of correlation cofficients, those 19 variables were eliminated from the analysis.

Simmons (1937) did not report on intercoder reliability, which in the 1930's was yet to be developed and made standard in holocultural research. Nevertheless, Simmons was aware of the problem of reliability in this type of research: "The extent to which scientific objectivity is jeopardized by imperfect information, conflicting reports, lack of preciseness in the sources, oversimplified and perhaps arbitrary classification, and inescapable subjective judgments is, at this point, woefully apparent. All that is claimed for the study, however, is that it represents a more reliable approximation to objective analysis than earlier and less well-controlled 
TABLE 2

Simmons' Variables with Score Frequencies

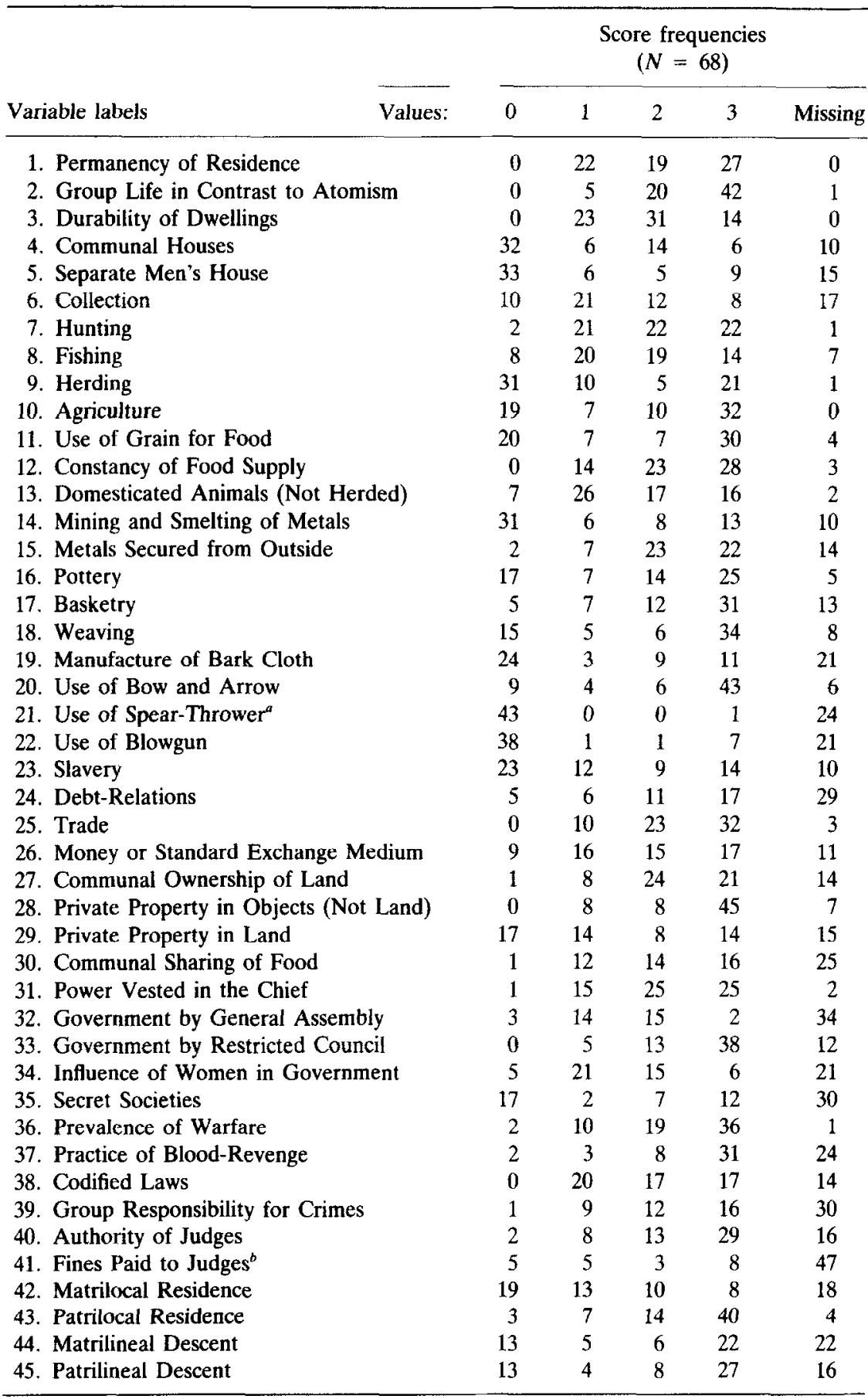


TABLE 2-Continued

\begin{tabular}{|c|c|c|c|c|c|}
\hline \multirow[b]{2}{*}{ Variable labels } & \multicolumn{5}{|c|}{$\begin{array}{l}\text { Score frequencies } \\
\quad(N=68)\end{array}$} \\
\hline & 0 & 1 & 2 & 3 & Missing \\
\hline 46. Matrilineal Inheritance & 18 & 5 & 8 & 12 & 25 \\
\hline 47. Patrilineal Inheritance & 7 & 8 & 11 & 34 & 8 \\
\hline 48. Matrilineal Succession & 13 & 5 & 6 & 8 & 36 \\
\hline 49. Patrilineal Succession & 6 & 4 & 13 & 31 & 14 \\
\hline 50. Matripotestal Family Authority & 10 & 6 & 7 & 7 & 38 \\
\hline 51. Patripotestal Family Authority & 5 & 3 & 8 & 40 & 12 \\
\hline 52. Avunculate & 2 & 14 & 6 & 14 & 32 \\
\hline 53. Ownership of Dwelling by Wife & 28 & 2 & 3 & 9 & 26 \\
\hline 54. Age-Grades ${ }^{b}$ & 3 & 3 & 8 & 8 & 46 \\
\hline 55. Hereditary Castes and Classes & 8 & 8 & 6 & 23 & 23 \\
\hline 56. Plutocracy & 2 & 9 & 13 & 29 & 15 \\
\hline 57. Exogamy re Kin-Group & 1 & 13 & 11 & 35 & 8 \\
\hline 58. Exogamy re Local Group ${ }^{b}$ & 8 & 3 & 10 & 4 & 43 \\
\hline 59. Group-Marriage ${ }^{a}$ & 48 & 1 & 1 & 1 & 17 \\
\hline 60. Polyandry ${ }^{a}$ & 50 & 2 & 2 & 1 & 13 \\
\hline 61. Polygyny & 6 & 11 & 16 & 33 & 2 \\
\hline 62. Monogamy & 0 & 9 & 19 & 31 & 9 \\
\hline 63. Betrothal of Infants and Children & 2 & 12 & 15 & 9 & 30 \\
\hline 64. Arranged Marriages (No Choice) & 1 & 6 & 18 & 38 & 5 \\
\hline 65. Marriage by Capture & 32 & 14 & 4 & 2 & 16 \\
\hline 66. Marriage by Purchase or Brideprice & 7 & 8 & 13 & 36 & 4 \\
\hline 67. Dowry (Payment by Bride's Family) & 22 & 9 & 5 & 9 & 23 \\
\hline 68. Wife-Lending or Wife-Exchange & 25 & 5 & 7 & 9 & 22 \\
\hline 69. Remarriage of Widow & 2 & 2 & 6 & 51 & 7 \\
\hline 70. Levirate & 4 & 9 & 6 & 30 & 19 \\
\hline 71. Funeral Suttee ${ }^{a}$ & 54 & 7 & 2 & 0 & 5 \\
\hline 72. Difficulty of Divorce for Women & 0 & 20 & 27 & 10 & 11 \\
\hline 73. Difficulty of Divorce for $\mathrm{Men}^{a}$ & 1 & 50 & 6 & 2 & 9 \\
\hline 74. Subjection or Inferiority of Women & 8 & 23 & 13 & 15 & 9 \\
\hline 75. Uncleanness of Women & 3 & 18 & 15 & 14 & 18 \\
\hline 76. Post-Marital Sex Restriction on Women & 0 & 7 & 23 & 30 & 8 \\
\hline 77. Mother-in-Law Avoidance & 3 & 3 & 4 & 19 & 39 \\
\hline 78. Primogeniture & 2 & 7 & 14 & 21 & 24 \\
\hline 79. Scalps and Heads Sought as Trophies ${ }^{b}$ & 7 & 0 & 6 & 15 & 40 \\
\hline 80. Property Rights in Women & 6 & 11 & 10 & 8 & 33 \\
\hline 81. Organized Priesthood (True Priests) & 13 & 21 & 5 & 15 & 14 \\
\hline 82. Prevalence of Shaminism ${ }^{a}$ & 0 & 1 & 12 & 55 & 0 \\
\hline 83. Ancestor Worship & 3 & 18 & 8 & 7 & 32 \\
\hline 84. Elaboration of Ceremony and Ritual & 0 & 14 & 18 & 24 & 12 \\
\hline 85. Legendary Heroes & 1 & 0 & 11 & 40 & 16 \\
\hline 86. Legendary Heroines & 0 & 2 & 12 & 23 & 31 \\
\hline 87. Human Sacrifice (Not Grave Escort) & 17 & 12 & 4 & 5 & 30 \\
\hline 88. Totemism & 10 & 9 & 11 & 11 & 27 \\
\hline 89. Fetishism ${ }^{b}$ & 1 & 1 & 14 & 6 & 46 \\
\hline 90. Cannibalism & 19 & 18 & 1 & 6 & 24 \\
\hline 91. Reincarnation ${ }^{b}$ & 2 & 4 & 5 & 5 & 52 \\
\hline 92. Intensity of Ghost-Fear & 0 & 2 & 12 & 47 & 7 \\
\hline
\end{tabular}


TABLE 2-Continued

\begin{tabular}{|c|c|c|c|c|c|c|}
\hline \multirow[b]{2}{*}{ Variable labels } & \multirow[b]{2}{*}{ Values: } & \multicolumn{5}{|c|}{$\begin{array}{l}\text { Score frequencies } \\
\quad(N=68)\end{array}$} \\
\hline & & 0 & 1 & 2 & 3 & Missing \\
\hline \multirow{3}{*}{\multicolumn{2}{|c|}{$\begin{array}{l}\text { 93. Exposure of the Dying } \\
\text { 94. Abandonment of the House of the Dead } \\
\text { 95. Grave Escort other than Widows }\end{array}$}} & 36 & 3 & 1 & 4 & 24 \\
\hline & & 26 & 5 & 4 & 14 & 19 \\
\hline & & 45 & 3 & 4 & 3 & 13 \\
\hline \multicolumn{2}{|c|}{ 96. Mortuary Sacrifice of Property } & 4 & 14 & 22 & 21 & 7 \\
\hline \multicolumn{2}{|l|}{ 97. Elaboration of Mortuary Ceremonies } & 0 & 6 & 33 & 21 & 8 \\
\hline \multicolumn{2}{|l|}{ 98. Attractiveness of Future Life } & 0 & 17 & 26 & 14 & 11 \\
\hline \multicolumn{2}{|l|}{ 99. Belief in Natural Death } & 16 & 25 & 3 & 1 & 23 \\
\hline \multicolumn{2}{|l|}{ 100. Circumcision ${ }^{b}$} & 9 & 1 & 1 & 16 & 41 \\
\hline \multicolumn{2}{|l|}{ 101. Infanticide } & 6 & 7 & 14 & 16 & 25 \\
\hline \multicolumn{2}{|l|}{ 102. Picture Writing ${ }^{b}$} & 5 & 6 & 1 & 4 & 52 \\
\hline \multicolumn{2}{|l|}{ 103. Written Language } & 34 & 2 & 1 & 5 & 26 \\
\hline \multicolumn{2}{|l|}{ 104. Couvade ${ }^{b}$} & 12 & 2 & 5 & 4 & 45 \\
\hline \multicolumn{2}{|l|}{ 105. Transmigration ${ }^{b}$} & 2 & 3 & 4 & 3 & 56 \\
\hline \multicolumn{2}{|l|}{ 106. Phallicism ${ }^{b}$} & 0 & 0 & 2 & 2 & 64 \\
\hline \multicolumn{2}{|l|}{ 107. Preference for Male Children ${ }^{a}$} & 0 & 1 & 4 & 32 & 31 \\
\hline \multicolumn{2}{|l|}{ 108. Preference for Female Children } & 0 & 3 & 13 & 20 & 32 \\
\hline \multicolumn{2}{|l|}{ 109. Preferred Status of First Wife ${ }^{h}$} & 1 & 0 & 3 & 10 & 54 \\
\hline
\end{tabular}

${ }^{a}$ Poorly distributed data.

${ }^{b}$ Data missing for 40 or more cases.

procedures" (Simmons, 1937, pp. 497-498). For lack of space, Simmons did not even identify in his 1937 paper the ethnographies from which he made his codings. However, he did subsequently publish bibliographic references for his 71 sample societies in his 1945 book on the aged.

Although a direct assessment of his coding reliability would thus be possible, it was more affordable and feasible to pursue an indirect examination of reliability. Strong and statistically significant correlations with comparable variables coded from ethnographies of the same societies would attest to the reliability of Simmons' sources and codings. As shown in Table 3, 29 such comparisons could be made for the 70 societies for which Simmons and Murdock had both coded data. Those of Murdock's variables which were coded with a multilevel ordinal scale were maintained thus. These were the subsistence economy codings of percentage dependence on "Gathering," "Hunting," "Fishing," "Husbandry," and "Agriculture" found in Columns 7 to 11 of the Atlas (1967). For other of Murdock's variables, nominal codings were used to calculate multilevel ordinal measures. For example, for comparison with Simmons' variable 23, "Slavery," Murdock's Column 71 was calculated as H (hereditary slavery) $=3, \mathrm{~S}$ (slavery even if nonhereditary) $=2, \mathrm{I}$ (incipient slavery) $=$ 1 , and $O$ (no slavery) $=0$. The five of Murdock's variables that were 
TABLE 3

Reliability of Simmons' Codings of Variables Regarding Murdock

\begin{tabular}{|c|c|c|}
\hline Simmons' variables & $\begin{array}{l}\text { Kendall } \\
\text { correlations }\end{array}$ & Murdock's variables \\
\hline 1. Permanent Residence & $.68^{* * *}(n=67)$ & m 30. Settlement Pattern \\
\hline 3. Durable Dwellings & $.36^{* * *}(n=61)$ & m 84. Roofing Material \\
\hline 6. Collection & $.68^{* * *}(n=50)$ & m 7. Gathering \\
\hline 7. Hunting & $.62^{* * *}(n=66)$ & m 8. Hunting \\
\hline 8. Fishing & $.62^{* * *}(n=60)$ & m 9. Fishing \\
\hline 9. Herding & $.71^{* * *}(n=66)$ & m 10. Animal Husbandry \\
\hline 10. Agriculture & $.74^{* * *}(n=67)$ & m 11. Agriculture \\
\hline 11. Use Grain for Food & $.45^{* *} \quad(n=43)$ & b 29. Principle Crop \\
\hline 13. Domesticated Animals & $.38^{* * *}(n=65)$ & b 39. Animal Husbandry \\
\hline 14. Mining and Smelting & $.73^{* * *}(n=54)$ & b 42. Metal Working \\
\hline 16. Pottery & $.72^{* * *}(n=55)$ & b 48 . Pottery \\
\hline 18. Weaving & $.59^{* * *}(n=53)$ & b 44 . Weaving \\
\hline 23. Slavery & $.62^{* * *}(n=57)$ & m 71 . Slavery \\
\hline 28. Property in Objects & $.48^{* * *}(n=52)$ & b 76. Inherit Moveables \\
\hline 29. Property in Land & $.65^{* * *}(n=40)$ & b 74. Inherit Land \\
\hline 42. Matrilocal Residence & $.45^{* * *}(n=51)$ & b 17. Marital Residence \\
\hline 43. Patrilocal Residence & $.57^{* * *}(n=63)$ & b 17. Marital Residence \\
\hline 46. Matri. Inheritance & $.63^{* * *}(n=31)$ & m $74+76$. Inheritance \\
\hline 47. Patri. Inheritance & $.54^{* * *}(n=43)$ & m $74+76$. Inheritance \\
\hline 48. Matri. Succession & $.56^{* * *}(n=27)$ & m 73. Succession to Headman \\
\hline 49. Patri. Succession & $.28^{*} \quad(n=44)$ & m 73. Succession to Headman \\
\hline 52. Avunculate & $.43^{* *} \quad(n=36)$ & b 17. Marital Residence \\
\hline 55. Castes and Classes & $.68^{* * *}(n=42)$ & m 67. Class Stratification \\
\hline 61. Polygyny & $.31^{* *} \quad(n=65)$ & b 14. Family Organization \\
\hline 62. Monogamy & $.33^{*} \quad(n=34)$ & b 14. Family Organization \\
\hline 66. Marriage by Purchase & $.49^{* * *}(n=63)$ & m 12. Mode of Marriage \\
\hline 67. Dowry & $.22 \mathrm{~ns}(n=44)$ & b 12. Mode of Marriage \\
\hline 78. Primogeniture & $.37^{*} \quad(n=36)$ & m $75+77$. Inheritance \\
\hline 100. Circumcision & $.82^{* * *}(n=27)$ & b 37. Circumcision \\
\hline
\end{tabular}

Note. ns $=$ not significant: $m=$ multiple level ordinal scale; $\mathrm{b}=$ binary ordinal scale.

${ }^{*} p<.05$.

${ }^{* *} p<.01$.

${ }^{* * *} p<.001$.

maintained as multilevel ordinal variables and the 10 that werc made into multilevel ordinal variables are designated by the symbol " $\mathrm{m}$ " in Table 3. The other 14 comparison variables were calculated as binary ordinal measures and are designated in Table 3 by "b". For example, with Murdock's variables 74 and 76 ("Inheritance of Real Property" and "Inheritance of Moveable Property"), ordinality was limited to the binary presence or absence of private ownership.

Thus for comparison purposes, Simmons' and Murdock's variables were all ordinal and had relatively small ranges, 0 to 3 for Simmons' data, and 
0 to 1 or at most 0 to 9 for Murdock's data. Because the data were ordinal, a nonparametric correlation was preferred. Because the small range of scores would cause many ties in a rank order calculation, the Kendall correlation was preferred over the Spearman correlation. Kendall correlations are generally lower than Pearson or Spearman correlations calculated on the same data. One-tailed estimates of probability were used because of expectations that the correlations would be positive.

As shown in Table 3, the correlations of Simmons' and Murdock's variables were reasonably strong and, with one exception, statistically significant. This attests to the reliability of Simmons' sources and his codings. Simmons' variable 67, "Dowry," had a nonsignificant, though positive, correlation with Murdock's comparable measure. Various ways of transforming Murdock's data and various ways of collapsing Simmons' data could not produce higher correlations for this variable. Of course, from this finding it is not possible to pinpoint the source of the unreliability or to assign fault to either Simmons or Murdock. It may be a problem of different categorization schemes. For example, for the Yakut, Samoans, and Kwakiutl, Simmons gave maximum values ("+") to both variable 66 ("Marriage by Purchase or Brideprice") and variable 67 ("Dowry"). Murdock coded these societies with "G" on his variable 12 , meaning "reciprocal exchange of gifts of substantial value." It may be that a high bride price and a high dowry together are the same as reciprocal gifting. On the other hand, Simmons gave the Lapps maximum values for brideprice and dowry, while Murdock coded the Lapps as "O", meaning "absence of any significant consideration." Whatever the reason for the low reliability of "Dowry," it was deleted from further analysis in this study.

Murdock had issued a caution aboout his property variables: "In actual application the codes for Columns 74 and 76 have proved inadequate, and the coded data in these columns should consequently be used only with great circumspection" (Murdock, 1967, p. 59). Unfortunately, Murdock did not elaborate on what the inadequacy was, but it should be noted that he did delete his "Inheritance of Real Property" variable from his 1981 Atlas of World Cultures. In the present study, successful reliability correlations were found for matrilineal and patrilineal inheritance, and for primogeniture. These reliabilities were based on information coded in Murdock's inheritance variables. Nevertheless, for the primary correlations in this study, only the presence or absence of private property in objects (Column 76) or in land (Column 74) was coded, not the details of the inheritance practices. With this restricted usc of Murdock's property variables, reasonably strong and statistically significant correlations were found with Simmons' comparable variables. Although Murdock did not state the reason for his concern and although these correlations did not examine all of the information claims of Murdock's variables 74 and 76, they would seem to be reliable as measures of private ownership. 
TABLE 4

Reliability of Simmons' Codings of Variables Compared to Other Simmons' Variables

\begin{tabular}{lcl}
\hline Simmons' variables & $\begin{array}{c}\text { Kendall } \\
\text { correlations }\end{array}$ & \multicolumn{1}{c}{ Simmons' variables } \\
\hline 27. Communal land ownership & $-.56^{* * *}(n=45)$ & 29. Private property in land \\
42. Matrilocal Residence & $-.77^{* * *}(n=49)$ & 43. Patrilocal Residence \\
44. Matrilineal Descent & $-.82^{* * *}(n=42)$ & 45. Patrilineal Descent \\
46. Matrilineal Inheritance & $-.59^{* * *}(n=41)$ & 47. Patrilineal Inheritance \\
48. Matrilineal Succession & $-.88^{* * *}(n=30)$ & 49. Patrilineal Succession \\
50. Matripotestal Authority & $-.76^{* * *}(n=29)$ & 51. Patripotestal Authority \\
61. Polygyny & $-.66^{* * *}(n=57)$ & 62. Monogamy \\
107. Prefer Male Child & $-.36^{* *}(n=34)$ & 108. Prefer Female Child \\
\hline
\end{tabular}

Note. $\mathrm{ns}=$ not significant.

${ }^{* *} p<.01$.

*** $p<.001$.

A further testimony to the reliability of Simmons' data can be found in the negative correlations of those of his variables which should be incompatible with one another. Correlations for eight such incompatibility pairings are shown in Table 4 . These were reasonably strong, in the negative direction, and were all statistically significant. For example, where communal land ownership was coded as present, private land ownership tended to be coded as absent, and vice versa. Where child gender preference was coded for females, it tended not to be coded for males, and vice versa. These negative correlations are not perfect $r=-1.00$ because it is possible, for example, to have communal and private land ownership regimes within the same society, and it is unlikely that all societies would be extremists, for example, on preference of one child gender over the other.

Thus, of 71 societies originally sampled by Simmons (1937), 68 represent unique culture clusters. Of the 109 variables originally coded by Simmons, 89 appear to have adequate and reliable data for ordinal, nonparametric analysis.

\section{RESULTS}

The primary goal of the analysis was to identify those characteristics of societies which correlate with the practice of private ownership. A secondary goal was to use multivariate procedures to interrelate those correlations to allow summary interpretations and speculative discussion. The intent of the analysis was to be statistically conservative and also consistent with the characteristics of Simmons' data base, namely, ordinal scale, with a range of four, and missing data on as many as 39 of the 68 cases. Therefore, the Kendall correlation was the statistic of choice, for 
TABLE 5

Kendall Correlations of Simmons' and Murdock's Property Variables

\begin{tabular}{lllll}
\hline & $\begin{array}{c}\text { Simmons 28: } \\
\text { objects }\end{array}$ & $\begin{array}{c}\text { Simmons 29: } \\
\text { land }\end{array}$ & $\begin{array}{c}\text { Murdock 74: } \\
\text { objects }\end{array}$ & $\begin{array}{c}\text { Murdock 76: } \\
\text { land }\end{array}$ \\
\hline Simmons 27: & $r=-.27^{* *}$ & $r=-.56^{* * *}$ & $r=.06 \mathrm{~ns}$ & $r=-.37^{* *}$ \\
$\quad \begin{array}{l}\text { common land } \\
\text { Simmons 28: }\end{array}$ & $n=48$ & $n=45$ & $n=42$ & $n=40$ \\
$\quad$ & $r=.45^{* * *}$ & $r=.48^{* * *}$ & $r=.43^{* * *}$ \\
objects & & $n=51$ & $n=52$ & $n=49$ \\
Simmons 29: & & & $r=.27^{*}$ & $r=.65^{* * *}$ \\
land & & $n=43$ & $n=40$ \\
Murdock 74: & & & $r=.41^{* *}$ \\
objects & & & $n=47$ \\
\hline
\end{tabular}

${ }^{*} p<.05$.

${ }^{* *} p<.01$.

${ }^{* * *} p<.001$.

the reasons stated earlier, and a nonparametric multivariate procedure, cluster analysis, was used for subsequent analyses of the significant correlations.

To compensate for any residual doubts about the reliability of Simmons' sources and/or codings, correlations were examined for four available measures of private property: (1) Simmons' variable 28, "Private Property in Objects," (2) Simmons' variable 29, "Private Property in Land," (3) Murdock's Column 74, "Inheritance of Real Property," and (4) Murdock's Column 76, "Inheritance of Moveable Property." As shown in Table 5, these four variables are highly intercorrelated and represent, to varying degrees, the institution of private ownership. Simmons' variable 27, "Communal Ownership of Land," however, was less tightly intercorrelated with the other property measures, and correlated in the wrong direction $(n=$ $42, r=.06, p>.05$ ) with Murdock's measure of ownership of objects. Perhaps because every society has some communal land, this measure apparently is not a reliable and consistent measure of private ownership and was therefore not included as a criterion measure.

Whether or not a trait had a significant correlation with the practice of private ownership was determined by two conjunctive criteria: (1) correlations of the same sign on all four property variables, and (2) significance at $p<.05$ for three of the four property variables. Under a null hypothesis of randomly distributed data, the probability of getting all four correlations positive or all four negative is $p=.125$. Independent of sign, the probability of getting at least three correlations significant in any of four possible combinations is $p=[.05 \times .05 \times .05] \times 4=.0005$. To this should be added the remote probability $(p<.0000063)$ of getting all four correlations significant at $p<.05$. Thus, the likelihood of meeting 
TABLE 6

Significant Kendall Correlations with Property Variables

\begin{tabular}{|c|c|c|c|c|c|c|c|c|}
\hline \multirow[b]{3}{*}{ Correlates } & \multicolumn{4}{|c|}{ From Simmons' data } & \multicolumn{4}{|c|}{ From Murdock's data } \\
\hline & \multicolumn{2}{|c|}{ 28. Objects } & \multicolumn{2}{|c|}{ 29. Land } & \multicolumn{2}{|c|}{ 74. Land } & \multicolumn{2}{|c|}{ 76. Objects } \\
\hline & $r$ & $n$ & $r$ & $n$ & $r$ & $n$ & $r$ & $n$ \\
\hline 1. Permanent Residence & $.24^{*}$ & 61 & $.34^{* *}$ & 53 & $.46^{* * *}$ & 52 & $.34^{* *}$ & 55 \\
\hline 10. Agriculture & $.18 \mathrm{~ns}$ & 61 & $.46^{* * *}$ & 53 & $.66^{* * *}$ & 52 & $.36^{* *}$ & 55 \\
\hline 11. Use Grain for Food & $.24^{*}$ & 58 & $.21^{*}$ & 50 & $.39^{* *}$ & 48 & $.37^{* *}$ & 51 \\
\hline 12. Constant Food Supply & $.17 \mathrm{~ns}$ & 59 & $.23^{*}$ & 50 & $.26^{*}$ & 49 & $.23^{*}$ & 52 \\
\hline 13. Domesticated Animals & $.10 \mathrm{~ns}$ & 59 & $.29^{* *}$ & 51 & $.43^{* * *}$ & 50 & $.22^{*}$ & 53 \\
\hline 23. Slavery & $.24^{*}$ & 54 & $.22^{*}$ & 48 & $.40^{* *}$ & 46 & $.34^{* *}$ & 48 \\
\hline 24. Debt-Relations & $.33^{*}$ & 37 & $.37^{* *}$ & 34 & $.45^{* *}$ & 30 & $.36^{*}$ & 33 \\
\hline 25. Trade & $.31^{* *}$ & 60 & $.26^{*}$ & 51 & $.37^{* *}$ & 51 & $.32^{* *}$ & 55 \\
\hline 26. Money & $.30^{* *}$ & 55 & $.45^{* * *}$ & 48 & $.39^{* *}$ & 45 & $.33^{* *}$ & 48 \\
\hline 30. Communal Food Sharing & $-.39^{* *}$ & 40 & $-.20 \mathrm{~ns}$ & 35 & $-.37^{*}$ & 34 & $-.40^{* *}$ & 36 \\
\hline 33. Government by Council & $.26^{*}$ & 52 & $.15 \mathrm{~ns}$ & 46 & $.28^{*}$ & 41 & $.35^{* *}$ & 45 \\
\hline 36. Warfare & $.09 \mathrm{~ns}$ & 60 & $.23^{*}$ & 52 & $.29^{*}$ & 52 & $.23^{*}$ & 54 \\
\hline 38. Codified Laws & $.26^{*}$ & 50 & $.28^{*}$ & 43 & $.48^{* * *}$ & 42 & $.29^{*}$ & 44 \\
\hline 40. Authority of Judges & $.30^{*}$ & 49 & $.34^{* *}$ & 44 & $.44^{* *}$ & 40 & $.43^{* *}$ & 43 \\
\hline 43. Patrilocal Residence & $.25^{*}$ & 57 & $.32^{* *}$ & 49 & $.27^{*}$ & 49 & $.23^{*}$ & 52 \\
\hline 55. Castes and Classes & $.29^{*}$ & 43 & $.32^{* *}$ & 41 & $.44^{* *}$ & 35 & $.37^{* *}$ & 39 \\
\hline 56. Plutocracy & $.43^{* * *}$ & 51 & $.41^{* * *}$ & 45 & $.51^{* * *}$ & 44 & $.34^{* *}$ & 47 \\
\hline 65. Marriage by Capture & $-.37^{* *}$ & 48 & $-.14 \mathrm{~ns}$ & 42 & $-.32^{*}$ & 40 & $-.24^{*}$ & 44 \\
\hline 84. Ceremony and Ritual & $.30^{* *}$ & 52 & $.21^{*}$ & 45 & $.26^{*}$ & 43 & $.34^{* *}$ & 48 \\
\hline 93. Exposure of the Dying & $-.35^{*}$ & 40 & $-.29^{*}$ & 36 & $-.27 \mathrm{~ns}$ & 32 & $-.38^{*}$ & 35 \\
\hline 94. Abandon House of the Dead & $-.19 \mathrm{~ns}$ & 45 & $-.54^{* * *}$ & 39 & $-.59^{* * *}$ & 38 & $-.36^{* *}$ & 39 \\
\hline
\end{tabular}

Note. ns $=$ not significant.

${ }^{*} p<.05$.

${ }^{* *} p<.01$.

*** $p<.001$.

the two-fold, conjunctive significance criteria is: $p<.125 \times .0005063=$ .0000633 , which is stringently conservative, to the point of sacrificing statistical power.

In all analyses, a one-tailed probability was used because of the expectation that all four of the property correlations would have the same sign. With the examination of 87 correlations, the likelihood of a spurious claim of correlation in this study is $p<.0055$. The problem of independent variables exceeding the number of cases was ignored because the data were not going to be subjected to a single, multivariate, parametric analysis. It was deemed more important to avoid arbitrary deletion of variables.

Of the 87 variables examined as correlates of private ownership, 21 passed the conservative criteria of significance. These traits are listed in Table 6. Of these, 17 were positive correlates of private ownership, and 
four were negative correlates. On no occasion did a variable correlate with both of Simmons' property variables without confirming correlations with both of Murdock's property variables. To simplify subsequent cluster analysis, the labels of the four negative correlates were changed to the negative so that the signs of their correlations with the ownership variables could be reversed and made positive.

Because these correlations were nonparametric and because they all had missing data (ranging from 7 to 38 missing cases), thcy could not be further analyzed by regression analysis or factor analysis. However, the data were amenable to hierarchical cluster analysis, which organizes variables into groups according to the correlational proximity of the variables to one another. The clustering algorithm used here was complete linkage, also known as the maximum distance method. The essential task of a clustering algorithm is to decide to which cluster a new variable should be assigned. A single linkage algorithm examines each cluster for the variable which is closest to the new variable and assigns by criteria of least distance. By contrast, the complete linkage algorithm examines each cluster for the variable which is most distant from the new variable and assigns by criteria of least, maximum-distance. Complete linkage produces compact, spherical clusters and avoids the chaining effects characteristic of single linkage (Mardia, Kent, and Bibby, 1979). It is important to bear in mind that with cluster analysis, as with all other multivariate procedurcs, there are no unique or "best" solutions. The results represent but one way the variables may be grouped for interpretive labelling and speculative discussion.

The results of the cluster analysis appear in Table 7. The dendrogram there depicted is essentially a matrix of Kendall correlations $(\times 100)$ organized so that higher correlations appear to the left. For example, the first value, 72, means that variable 1 had a Kendall correlation of $r=$ .72 with variable 10 . The second value, 55 , means that variable 1 had a Kendall correlation of $r=.55$ with the negation of variable 94, and so forth.

In the cluster dendrogram, three distinct clusters are evident, each made up of two smaller subclusters. The first cluster might be labelled "the social ecology of agriculture." Its first subcluster consists of "Permanency of Residence," "Agriculture," "NOT Abandonment of the House of the Dead," and "Domesticated Animals (Other than Herded)." This appears to represent the capital side of agricultural production. The second subcluster consists of "Use of Grain for Food," "Slavery," and "Prevalence of Warfare." This appears to represent the labor or perhaps consumption sides of agricultural society.

The second cluster might be labelled "social and material stratification." The first subcluster consists of "Debt-Relations," "Hereditary Castes and Classes," and "Plutocracy," clearly representing hierarchical social rela- 
TABLE 7

Cluster Analysis of Significant Property Correlates

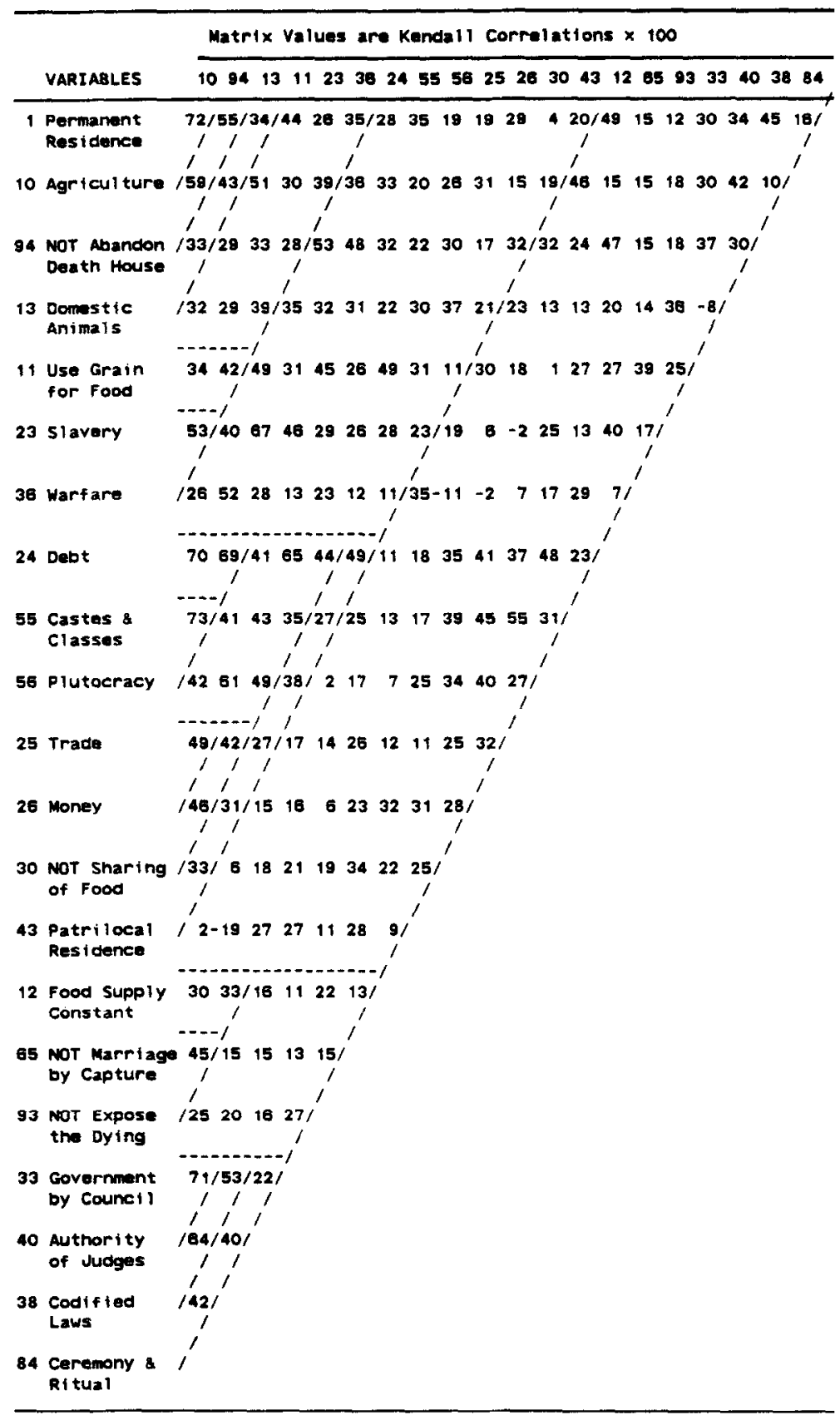


tions. The second subcluster consists of "Trade," "Money or Standard Exchange Medium," and "NOT Communal Sharing of Food." This would seem to represent material stratification and exchange across stratification gradients. "Patrilocal Residence" was not a part of either subcluster, but its strong and consistent linkage to other members of this cluster suggests that patrilocal residence practices somehow serve or reflect the wealth gradient of social stratification.

The third cluster might be labelled "social security." Its first subcluster consists of "Constancy of Food Supply," "NOT Marriage by Capture," and "NOT Exposure of the Dying." These would seem to represent physical security for the individuals in the society. The second subcluster consists of "Government by Restricted Council," "Authority of Judges," "Codified Laws," and "Elaboration of Ceremony and Ritual," perhaps representing the institutionalization of social order. If Simmons' private property variables (28 and 29) are entered into the cluster analysis, they link with each other and. form a third subcluster between the other two subclusters of the "social security" cluster.

\section{DISCUSSION}

Simmons closed his own discussion with caution and humility:

To the writer, the statistical discipline has proved to be an effective instrument for the integration of masses of facts into mosaics of apparent order and sense. It has, moreover, been of inestimable use in calling attention to contrary facts, and thus in applying the brake to overzealous generalizations. The actual results, of course, are in the highest degree only tentative. In addition to the defects already pointed out, e.g. the intrusion of subjective judgments and the use of a possibly arbitrary system of classification, the study suffers from insufficiency of data. Seventy-one tribes are too few to justify placing much reliance upon any single statistical coefficient. . . . No question can be considered settled by a study as incomplete as our own. But records of pertinent and painstaking investigation serve their purpose when they tip the scales ever so slightly. (Simmons, 1937, p. 517.)

Indeed, there are inherent uncertainties in holocultural research that drive discussion toward speculation rather than toward conclusion. Three such uncertainties require attention before beginning discussion of the results of this study.

The first difficulty is the nonrandom sampling of societies. Although Simmons (1937) had sampled societies so as to achieve climatic, geographic, racial, and cultural representativeness, he did not claim random sampling. At that point in the history of holocultural research, random sampling had only just been advocated, by Beaglehole (1932). He had argued that cross-cultural studies, particularly on property, should employ random sampling in order to avoid the ideological biases that plagued 19 th century cross-cultural research. Anything can be demonstrated if 
case societies are selected rather than randomly sampled. However, since all holocultural research samples from the available ethnographies, none of it employs random sampling in the true sense that all cultures have an equal chance of being included in the analysis. Tatje, Naroll, and Textor (1970) examined Simmons' data base for representativeness and faulted it for overrepresenting societies from "very harsh" environments.

In Simmons' (1937) sample, it is not possible to now rule out systematic selection biases, or bias in the selection of some cases. However, for several reasons, it appears that there was little bias, if any, in his selection of case societies. First, Simmons (1937) strongly expressed concern about subjective effects contaminating the research and was apparently motivated to minimize such contamination. Second, one of his main interests was the ownership of land, which he discussed first and most frequently and for which he provided two variables (27 and 29). Yet, for these two variables, the number of cases with missing data was 16 and 17 respectively, which is not what one would expect if there were an intentional bias in case selection. Finally, many of Simmons' expectations were disconfirmed by his own data and analysis.

The second difficulty is that the design and method of the study are correlational. This requires the usual caveat that it is not possible to distinguish which correlates, or clusters of correlates, are precedent to, or more strongly "causes of," private ownership and which are subsequent, or "effects." There are the further possibilities that private ownership and its correlates are merely surface manifestations of common deeper factors, or that correlates of private ownership are not supportive of ownership as consequents or subsequents, but are antithetical concomitants, in the sense of counterbalances or compensations. Thus, for example, it may be that the appearance of social security practices causes private property to arise as another mechanism of social security. Or, it may be that private ownership causes social security practices to arise as other mechanisms of private rights. Or, it may be that both arise because of a theology or ideology of individualism. Or, it may be that private ownership threatens social security (or vice versa) and that the appearance of one causes or depends upon the other as a counterbalance. Mere correlation is indeterminate and does not induce confidence in discussions based only on the facts of correlation.

The third difficulty is the still worrisome concern about the reliability of the ethnographic sources which form the basis for Simmons' codings, for Murdocks' codings, and indeed, for any codings based on the accumulated ethnographic record. Even though Simmons and Murdock have reasonable agreement in their codings of ethnographies, if those ethnographies are unreliable for deeper historical, cultural, or conceptual reasons, then there is an unreliability which even conservative statistical procedures have difficulty overcoming. 
This concern is especially warranted in cross-cultural studies of property. Aboriginal peoples in various parts of the world are now arguing in public forums and in courts of law that their traditional cultures do have systems of land ownership which anthropologists have overlooked or misrepresented and which must now be acknowledged and respected. Richardson (1975) and Chatwin (1987) have aptly described such cases in North America and Australia respectively. Such claims are not without ethnographic support, even in the historical record (e.g., Speck, 1915; Davidson, 1928).

Yet Murdock's (1967) Ethnographic Atlas reports, for example, that only $22 \%$ of the 219 North American societies and none of the eight Australian societies, have private property in land. For those parts of the world in which European peoples have been settling and have been dispossessing and displacing aboriginal peoples, there is a surprisingly high rate of "no information" about aboriginal ownership of land. For North America, the "no information" rate is $34 \%$, for Insular Pacific $31 \%$, and for South America $57 \%$. This is in marked contrast to rates of $15 \%$ in Africa, $18 \%$ in the Circum-Mediterranean region, and $18 \%$ in East Eurasia, regions in which there has been much less displacement of indigenous peoples by European settlers. Indeed, it would seem convenient, even provident, to lack information about land ownership just when dispossession and displacement are in progress. For North American ethnographies done in the 18th and 19th centuries, when the process of dispossession was at its greatest, Murdock's (1967) data show that almost $90 \%$ report no land ownership or no information about land ownership. After 1900 , after the dispossession was nearly complete, this figure drops to $50 \%$.

Such fundamental unreliability in the ethnographic record on property may also be due to ethnographers' impoverished conceptualizations of ownership. The question, "What is ownership?" has been studied and debated in Western Civilization for over two millennia, without consensus or conclusion. It seems unlikely that ethnographers, or coders of ethnographies, would have a full grasp of the conceptual complexities of ownership. As Finnegan and Horton noted: "The most serious single source of misinterpretation of the concepts of alien cultures is inadequate mastery of the concepts of one's own culture" (Finnegan and Horton, 1973, p. 34). It is quite plausible that the presence or absence of ownership was determined by very limited criteria, such as the right of commercial alienation, or in Murdock's case, the right of testate. "Can you sell your land?" "No," and therc goes a whole society's claim to the ownership of land. Rather than reporting ownership, which is an inference, ethnographers and coders of ethnographies should be reporting on the many and various practices upon which an inference of ownership might be based, for example, trespass, sanctions for trespass, boundary marking, 
inheritance rules, occupancy, stewardship responsibilities, land use restrictions, commercial alienation, lending and borrowing, adverse possession, dispute adjudication, transfer mechanisms, etc. This is the point of Snare's (1972) argument, "It is a mistake to suppose that a society either has the institution of property or else lacks it completely" (p. 204). In this sense, Murdock's property variables are exemplary because he has made explicit the criterion upon which the inference of ownership is based.

Keeping in mind these concerns about sampling bias, correlational indeterminacy, and ethnographic unreliability, the results of this study do address several issues of speculative discussion. The first issue, set in the questionable discourse of classical theories of cultural evolution, concerns the origins of private property as a social institution. A second issue concerns the relationship of property to power.

Much of the classical discussion of private property has been concerned with its origins as a social institution. This has presumed that there is a natural history for social institutions; that is, that there is a necessary and universal sequence of evolutionary development for social institutions. It also has presumed that present variations in cultures represent historical stages of cultural development. Both of these presumptions are questionable. Nevertheless, two major theories within this tradition are (1) that property arose with the development of agriculture (e.g., Rousseau, 1754/1964; Morgan, 1877; Sumner and Keller, 1927), and (2) that property arose with the subjugation of women by men (e.g., Morgan, 1877; Engels, 1884/1902; Sumner and Keller, 1927; Mead, 1982; Newman, 1983).

This present reanalysis of Simmons' data supports the first theory but not the second. Private ownership seems to coincide with the social ecology of agriculture, not subsistence styles of agriculture, but systematic, organized agriculture which entails beasts of burden, slaves, grain storage, and organized warfare for territory and slaves.

However, the theory that private property is apiece with the subjugation of women found surprisingly little support, despite the fact that 32 of the 87 variables examined were gender defined (variables 5, 34, 42, 43, 44, $45,46,47,48,49,50,51,52,53,61,62,65,66,67,68,69,70,72,74$, $75,76,77,78,80,85,86,108)$. The only gender variables to correlate with private ownership were variable 43, "Patrilocal Residence," and variable 65, "Marriage by Capture." The latter was a negative correlate, which, if anything, links property to improved treatment of women. One variable explicitly defined as "Subjugation or Inferiority of Women" (variable 74) had a completely indifferent pattern of correlations with Simmons' measure of private ownership of objects $(n=53, r=.02, p>.40)$, with his measure of private ownership of land $(n=.46, r=-.09, p>.20)$, with Murdock's measure of property rights in land $(n=45, r=.00$, $p=.50)$, and with Murdock's measure of property rights in objects $(n=$ 
$50, r=.14, p>.10$ ). Hobhuse, Wheeler, and Ginsberg (1915) similarly concluded that the status of women was relatively unrelated to property institutions.

This raises a more general concern. Much of the theory and discussion of the social evolutionary origins of private property has been developed and presented by those who are ideologically hostile to private property. This hostility stems primarily from the social stratification and inequalities of power with which private property seems to correlate. In this study, those correlates of property appeared in cluster 2. Although the positive aspects of stratification are generally overlooked, Hobhouse, Wheeler and Ginsberg (1915) argued that they are an integral part of the development of private property.

With the decline of infanticide, the better security of food, and the extension of
order, we may infer a growing population, in some cases a desire for territorial
extension, in others a demand for slave labour. The mere extension of regular
industry makes for social differentiation, since the effects of encrgy and thrift
become cumulative. Hence we have the partial rise of a nobility and the more
extensive development of a servile or semi-servile class. Hence, also, the communal
tenure of land gives way, and while in some cases it blends with individual oc-
cupation and ownership, in others it passes more or less effectively into the hands
of a chief or a nobility. On all sides social and economic differentiation replace
the comparative equality of the hunting peoples. The extension of order is also,
upon the whole, an extension of subordination. (Hobhouse, Wheeler and Ginsberg,
1915, p. 254.)

Simmons (1945, p. 36) similarly concluded that "property rights have been lifesavers for the aged." Certainly, the third cluster of correlates of private property, here labelled "social security," seems to accord well with this interpretation. Posner (1980), a contemporary champion of private rights, has called this the insurance principle and has argued that it is primary among the economic values operating in primitive societies.

This leads to the second major issue, the relationship of property to power. In the results of this study, the second cluster of correlates of private property, here labelled "social and material stratification," clearly depicts power differentiation. Surprisingly, the private possession of food (variable 30) was unrelated to "Constancy of the Food Supply" (variable 12) but was closely related to "Debt-Relations" (variable 24), "Plutocracy" (variable 56), "Patrilocal Residence" (variable 43), and other of the stratification variables. It would seem that property rights in food might play an important role in the institution of private property, as has been argued by Furby (1978) and by Hachamovitch (1989). The power of food may be as much social and psychological as biological.

The idea that private property is a form of interpersonal dominance and social power has appeared throughout Western history. The most prominent advocates of this would include St. Augustine (Schlatter, 1951), 
Rousseau (1754/1964), Stirner (Paterson, 1971), and Marx and Engels (1872). However, within the history of the psychology of property (Rudmin, 1988a), this idea has almost always appeared in company with the idea that property manifests and extends the self. That is, property is dominance and power which, for good or ill, serve the security and success of the self. In the sixth century B.C., Pythagoras advocated a pantheistic, egalitarian theology which held that all creation has a common god-head and that the individual self is a materialistic illusion (DeVogel, 1966; Heninger, 1974). Accordingly, Pythagoras banned private property because it is socially divisive, leads to stratification, and hinders transcendence. For much the same reasons, Plato banned private property for the ruling class of his Republic (1907). Aristotle (1952) opposed Plato's communism by arguing that private property was an expression of self love, and that private property, including slavery, provided the leisure and the resources for friendship, benevolence, and participation in politics, which were all necessary for self development. Aquinas revived Aristotle's arguments that love of the self, and therefore private property, are natural and virtuous and allow the extension of the person into political affairs (Fredrickson, 1954).

Even for the materialistic theorists of the seventeenth century, such as Descartes, Hobbes, and Malebranche, private property resulted from the self-regarding tendencies of self preservation and the striving for superiority (Drever, 1917). In the modern era, William James (1890) is the most quoted champion of the idea that property is a part of the self, but his metaphors of dominance and ascendency are commonly overlooked:

\footnotetext{
We feel and act about certain things that are ours very much as we feel and act about ourselves. Our fame, our children, the work of our hands, may be as dear to us as our bodies are, and arouse the same feelings and the same acts of reprisal if attacked. . . . In its widest possible sense. . . a man's Self is the sum total of all that he CAN call his, not only his body and his psychic powers, but his clothes and his house, his wife and children, his ancestors and friends, his reputation and works, his lands and horses, and yacht and bank-account. All these things give him the same emotions. If they wax and prosper, he feels triumphant; if they dwindle and die away, he feels cast down. (James, 1890, Vol. 1, p. 291.)
}

Metaphors of power are very evident in his description of the loss of valued possessions: "We are all at once assimilated to the tramps and poor devils whom we so despise, and at the same time removed farther than ever away from the happy sons of the earth who lord it over land and sea and men in the full-blown lustihood that wealth and power can give. ..." (James, 1890, Vol. 1, p. 293).

Others have since argued, from various perspectives, that possessions and property are means of dominance and power for the protection and benefit of the self. For example, Cooley (1902), Lattke (1936), Schachter, 
Kirshner, Klips, Friedricks, and Sanders (1974), Furby (1980), Charney (1980), Levine (1983) and others have linked self definition in children to the dominance aspects of possession. Marcel (1949) and George Mead (1982) have both argued that property creates an existential boundary for the self and a hostile orientation toward 'the other' outside that boundary. Furthermore, the power aspects of property may serve not only the aggressive assertion of the self but also its defense. For example, in the psychoanalytic tradition, Suttie, (1935) and Horney (1937) have both argued that possessions and property are defensive means of coping with the anxieties of helplessness, insignificance, and separation. Fromm (1976) considers this a neurotic 'having' mode of existence. Property is thus a prop for the self (Goffman, 1961). Rudmin (1988c) found that the traits of defendence and materialism (encompassing possessiveness, envy, and nongenerousity) were strongly correlated, supporting the arguments that possessions psychologically empower, or are empowered by, the defense of the self.

The thrust of this discussion is to speculate that perhaps all three of the clusters of property correlates found in this study are manifestations of underlying values of self regard and individualism. The institution of private property serves the security of the self. Securing possessions as private property in order to fabricate, maintain, extend, and defend the self is important only if the individual self is deemed important. If the self is valued within a culture so too should be the defensive and empowering mechanism of private property. From this speculative perspective, the variables in the "social ecology of agriculture" cluster would represent permanence and security in geography and in sustenance. The variables in the "social and material stratification" cluster would represent the dominance and power stratifications that arise if the self is secured by the boundary mechanisms of private property. Finally, the variables in the "social security" cluster would represent physical and institutional security for the individual within the social system.

Such an interpretation would accord with the earlier finding by Rudmin (1988b) that preference for dominance was the strongest cross-cultural correlate of favorable attitudes toward the institution of private property but was moderated within cultures by preferences for individual autonomy. The more a society values individualism, the more preferences for dominance and private property are correlated. Evidence for and against this interpretation might also be sought in the reexamination of other existing holocultural data bases on property. Or, when the historical record of comparative research has been restored, in new comparative studies designed to test specific hypotheses.

\section{REFERENCES}

Aristotle. (1952). The Politics of Aristotle (E. Barker, Trans.), Oxford University Press, London. 
Averkieva, I. P. (1961). "The problem of property in contemporary American ethnography," Sovetskaya Etnografia 1, 50-63.

Beaglehole, E. (1932). Property: A Study in Social Psychology, Macmillan, New York.

Bloombaum, M. (1968). "Tribes and traits: A smallest space analysis of cross-cultural data," American Anthropologist 70, 328-330.

Charney, R. (1980). "Speech roles and the development of personal pronouns," Journal of Child Language 7, 509-528.

Chatwin, B. (1987). The Songlines, Viking Penquin, New York.

Cooley, C. H. (1902). Human Nature and the Social Order, Scribners, New York.

Coontz, S., and Henderson, P. (Eds.) (1986). Women's Work, Men's Property: The Origins of Gender and Class, Verso, London.

Davidson, D. S. (1928). "The family hunting territory in Australia," American Anthropologist 30, 614-631.

DeVogel, C. J. (1966), Pythagoras and Early Pythagoreanism, Van Gorcum, Assen.

Drever, J. (1917). Instinct in Man: A Contribution to the Psychology of Education, Cambridge University Press, Cambridge.

Engels, F. (1902). The Origin of the Family, Private Property, and the State (E. Untermann, Trans.), Kerr, Chicago. (Originally published in 1884.)

Ensor, G. (1844). Of Property and its Equal Distribution, Effingham Wilson, London.

Finnegan, R., and Horton, R. (1973). "Introduction," in Modes of Thought (R. Horton and R. Finnegan, Eds.), Faber and Faber, London.

Fredrickson, O. P. (1954). The Psychology of Ownership, Catholic University of America Press, Washington, D.C.

Fromm, E. (1976). To Have or to Be? Harper \& Row, New York.

Furby, L. (1978). "Possessions: Toward a theory of their meaning and function throughout the life cycle," in Life-Span Development and Behavior (P. B. Baltes, Ed.), pp. 297336, Academic Press, New York.

Furby, L. (1980). "The origins and early development of possessive behavior," Political Psychology 2, 30-42.

Fustel de Coulanges, N. D. (1885). Recherches sur quelques Problems d'Histoire, Hachette, Paris.

Fustel de Coulanges, N. D. (1891a). The Origins of Property in Land (M. Ashley, Trans.), Sonnenschein, London.

Fustel de Coulanges, N. D. (1891b). Nouvelle Recherches sur quelques Problems d'Histoire, Hachette, Paris.

Goffman, E. (1961). Asylums, Anchor, Garden City, NY.

Gouldner, A. W., and Peterson, R. A. (1962). Notes on Technology and the Moral Order. Bobbs-Merrill, Indianapolis.

Guyot, Y. (1895). La Propriété: Origine et Évolution, Delgrave, Paris.

Hachamovitch, Y. (1989). "Of a mouth to a flesh: A semiotic of moveable bodies," in Law and Semiotics (R. Kevelson, Ed.), Vol. 3, pp. 149-166, Plenum Press, New York.

Heise, D., Lenski, G., and Wardwell, J. (1976). "Further notes on technology and the moral order," Social Forces 55, 316-337.

Heninger, S. K. (1974). Touches of Sweet Harmony: Pythagorean Cosmology and Renaissance Poetics, Huntington Library, San Marino, CA.

Hobhouse, L. T., Wheeler, G., and Ginsberg, M. (1915). The Material Culture and Social Institutions of the Simpler Peoples: An Essay in Correlation, Chapman \& Hall, London.

Horney, K. (1937). The Neurotic Personality of Our Time, Norton, New York.

James, W. (1890). Principles of Psychology, Ilolt, New York.

LaFargue, P. (1885). Propriété: Origine et Évolution: These Communiste, Delagrave, Paris.

LaFargue, P. (1890). The Evolution of Property from Savagery to Civilization, Swan Sonnerschein, London. 
LaFargue, P. (1892). Le Communisme et l'Évolution Économique, Lille.

Lattke, H. (1936). Ueber das Verhaeltnis von Kindern zum Eigentum, Scheur, Bonn.

Laveleye, E. L. V., de (1878). Primitive Property (G. Marriott, Trans.), Macmillan, London.

Laveleye, E. L. V., de (1891). De la Propriété et de ses Formes Primitives, Macmillan, London.

Letourneau, C. (1892). Propcrty: Its Origins and Development, Charles Scribner's Sons, London.

Levine, E. L. (1983). "Mine: Self-definition in 2-year-old boys," Developmental Psychology 19, 544-549.

Levinson, D., and Malone, M. J. (1980). Toward Explaining Human Culture: A Critical Review of the Findings of Worldwide Cross-Cultural Research, HRAF Press, New Haven.

Lewinski, J. (1913). The Origin of Property and the Formation of the Village Community, Constable, London.

Locke, J. (1952). The Second Treatise on Government, Bobbs-Merrill, New York. (Originally published in 1690.)

Marcel, G. (1949). Being and Having: An Existential Diary (K. Farmer, Trans.), Harper, New York.

Mardia, K. V., Kent, J. T., and Bibby, J. M. (1979). Multivariate Analysis, Academic Press, Toronto.

Marx, K., and Engels, F. (1872). Manifesto of the Communist Party, London.

Mead, G. H. (1982). The Individual and the Social Self: The Unpublished Work of George Herbert Mead (D. L. Miller, Ed.), University of Chicago Press, Chicago.

Morgan, L. (1877). Ancient Society, Holt, New York.

Murdock, G. P. (1949). Social Structure, Macmillan, New York.

Murdock, G. P. (1967). Ethnographic Atlas, University of Pittsburg Press, Pittsburg.

Murdock, G. P. (1981). Atlas of World Cultures, University of Pittsburg Press, Pittsburg.

Newman, K. S. (1983). Law and Economic Organization: A Comparative Study of Preindustrial Societies, Cambridge University Press, Cambridge.

Parker, C. S. (1905). The Euahlayi Tribe: A Study of Aboriginal Life in Australia, Constable, London.

Paterson, R. W. K. (1971). The Nihilistic Egoist: Max Stirner, Oxford University Press, London.

Petrucci, R. (1905). Les Origines Naturelles de la Propriété: Essai de Sociologie Comparée, Giard \& Briere, Paris.

Plato (1907). The Republic (A. D. Lindsay, Trans.), Dent, London.

Posner, R. A. (1980). "A theory of primitive society with special reference to law," Journal of Law and Economics 23, 1-53.

Richardson, B. (1975). Strangers Devour the Land, Macmillan, Toronto.

Rousseau, J.-J. (1964). Discours sur L'Origine et les Fondemens de l'Inégalité parmi les Hommes (reprinted in J.-J. Rousseau, Oeuvres Completes. Vol. 3), Gallimard, Paris. (Originally published in 1754.)

Rudmin, F. W. (1988a). Ownership as Interpersonal Dominance: A History and Three Studies of the Social Psychology of Property, Doctoral thesis, Queen's University, Kingston, Ontario, Canada.

Rudmin, F. W. (1988b). "Dominance, social control, and ownership: A history and a crosscultural study of motivations for private property," Behavior Science Research 22, 130160. [Note: The first two galleys were reversed during printing. The paper should begin on paragraph 5 on page 132. Paragraphs 1 through 4 should follow paragraph 8 on page 133.]

Rudmin, F. W. (1988c). "Personality traits and the meaning of ownership," in Proceedings 
of the Division of Consumer Psychology, Division 23: 1987 Annual Convention of the American Psychological Association, New York, August 28-September 1, 1987 (L. F. Alwitt, Ed.), pp. 39-45, Lynn R. Kahle, University of Orcgon, Eugene, OR.

Rudmin, F. W., Belk, R. W., and Furby, L. (1987). Social Science Bibliography on Property, Ownership, and Possession: 1580 Citations from Psychology, Anthropology, Sociology and Related Disciplines, Vance, Monticello, IL.

Schachter, F. F., Kirshner, K., Klips, B., Friedricks, M., and Sanders, K. (1974). Everyday Preschool Interpersonal Speech Usage: Methodological, Developmental, and Sociolinguistic Studies, (Monographs of the Society for Research in Child Development 39, no. 3), University of Chicago Press, Chicago.

Schlatter, R. (1951). Private Property: The History of an Idea, Rutgers University Press, New Brunswick, NJ.

Simmons, L. W. (1937). "Statistical correlations in the science of society," in Studies in the Science of Society (G. P. Murdock, Ed.), pp. 493-517, Yale University Press, New Haven.

Simmons, L. W. (1945). The Role of the Aged in Primitive Society. Yale University Press, New Haven.

Snare, F. (1972). "The concept of property," American Philosophical Quarterly 9, 200206.

Speck, F. G. (1915). "The family hunting band as the basis of Algonkian social organization," American Anthropologist 17, 289-305.

Spencer, H. (1893). The Principles of Sociology, Appleton, New York. (Originally published in 1879.)

Sumner, W. G., and Keller, A. G. (1927). The Science of Society, Yale University Press, New Haven.

Suttie, I. D., (1935). "Symposium on property and possessiveness," Journal of Medical Psychology 15, 51-62.

Swanson, G. E. (1960). The Birth of the Gods: The Origin of Primitive Beliefs, University of Michigan Press, Ann Arbor.

Tatje, T., Naroll, R. and Textor, R. B. (1970). "Methodological findings of the CrossCultural Summary," in A Handbook of Method in Cultural Anthropology (R. Naroll and R. Cohn, Eds.), pp. 649-675, Natural History Press, New York.

Veblen, T. (1898). "Beginnings of ownership," American Journal of Sociology 4, 352-365.

Veblen, T. (1912). The Theory of the Leisure Class, Macmillan, New York. (Originally published in 1899.)

Westermarck, E. (1908a). "Eigentumsempfindung und Diebstahlsrecht Insbesondere bei den Naturvolkern," Zeitschrift fuer Socialwissenschaft 11, 395-413.

Westermarck, E. (1908b). The Origin and Development of the Moral Ideas, Macmillan, London. 